\title{
MEKANISME CORPORATE GOVERNANCE DAN NILAI PERUSAHAAN
}

\author{
Nia Yuniarsih \\ Program Studi Akuntansi \\ Fakultas Ekonomi Universitas Katolik Darma Cendika \\ Jalan Dr. Ir. H. Soekarno 201, Surabaya
}

\begin{abstract}
The objective of this study is to examine the influence of corporate governance mechanism, namely managerial ownership, institutional ownership, to firm value. This study takes sample from 32 companies in the manufacturing sector at the Indonesia Stock Exchange, which were published in financial report from 20122013. The method of analysis of this research used multi regression and single regression. The results of this study show that (1) managerial ownership had positive significant influence to firm value, (2) institutional ownership had not significant influence to firm value, (3) simultaneously of managerial ownership, institutional ownership, had significant influence to firm value.
\end{abstract}

\begin{abstract}
ABSTRAK
Tujuan dari penelitian ini adalah untuk menjelaskan pengaruh mekanisme corporate governance (kepemilikan manajemen dan kepemilikan institusional) terhadap nilai perusahaan. Penelitian ini mengambil sampel 32 perusahaan manufaktur yang terdaftar di Bursa Efek Indonesia yang menerbitkan laporan keuangan tahun 2012 sampai dengan 2013. Metode analisis yang digunakan adalah regresi berganda dan regresi parsial. Hasil dari penelitian ini menunjukkan bahwa (1) kepemilikan manajemen berpengaruh positif terhadap nilai perusahaan, (2) kepemilikan isntitusional tidak berpengaruh terhadap nilai perusahaan, (3) secara bersama sama kepemilikan manajerial dan kepemilikan institusional berpengaruh terhadap nilai perusahaan.
\end{abstract}

Keywords: corporate governance mechanism, managerial ownership, institutional ownership, firm value

\section{PENDAHULUAN}

Masyarakat Ekonomi ASEAN (MEA) akan diberlakukan mulai tahun 2015. Yang melatar belakangi MEA adalah keinginan negara-negara anggota The Association of Southest
Asian Nation (ASEAN) menjadi kawasan yang diperhitungkan dalam perekonomian Internasional. Para Pemimpin ASEAN telah sepakat untuk mewujudkan MEA pada tahun 2015 dengan 4 pilar, yaitu (1) pasar tunggal 
dan basis produksi, (2) kawasan ekonomi berdaya saing tinggi, (3) kawasan dengan pembangunan ekonomi yang setara, dan (4) kawasan yang terintegrasi penuh dengan ekonomi global. Harapannya sebelum 2015 semua perdagangan bebas dari biaya tarif yang selama ini menjadi kendala perdagangan antar negara. MEA tidak hanya memberikan tantangan bersifat internal di dalam negeri saja tetapi persaingan dengan sesama negara ASEAN dan negara lain di luar ASEAN seperti China, India dan Korea.

Penerapan Good Corporate Governance (GCG) pada emiten dan perusahaan terbuka menjadi hal yang penting dalam menghadapi MEA tahun 2015 mendatang. Penerapan ini termasuk kepada perusahaan-perusahaan yang bergerak di industri manufaktur. Bank Dunia melansir, sektor manufaktur merupakan pendorong utama pertumbuhan ekonomi yang berkualitas, cepat dan stabil. Sektor manufaktur itu dinilai lebih tahan terhadap fluktuasi harga di pasar internasional sehingga besarnya kontribusi manufaktur terhadap produk domestik bruto (PDB) mendukung kestabilan ekonomi suatu negara.

Mekanisme corporate governance merupakan suatu mekanisme yang dapat meningkatkan efisiensi yang meliputi serangkaian hubngan antara manajemen perusahaan, dewan komisaris, para pemegang saham dan stakeholders lainnya. Ujiyantho dan Pramuka (2007) menyatakan bahwa terdapat empat mekanisme corporate governance yaitu memperbesar kepemilikan saham perusahaan oleh manajemen, kepemilikan saham oleh investor institusional, proporsi dewan komisaris independen dan ukuran dewan komisaris. Dua aspek yang perlu dipertimbangkan antara lain (1) konsentrasi kepemilikan perusahaan oleh pihak luar (outsider ownership concentration) dan (2) kepemilikan perusahaan oleh manajer (manager ownership). Pemilik perusahaan dari pihak luar berbeda dengan manajer karena kecil kemungkinannya pemilik dari pihak luar terlibat dalam urusan bisnis perusahaan sehari-hari.

Kepemilikan manajemen memiliki pengaruh terhadap nilai perusahaan. Apabila nilai perusahaan meningkat pihak manajemen yang memiliki kepemilikan saham berusaha untuk mendapatkan insentif dengan menyeimbangkan kepentingan antara pihak internal perusahaan dan eksternal perusahaan (Wahyudi dan Pawestri, 2006). Secara teori, manajer merupakan agen atau wakil pemilik, namun dalam prakteknya mereka sebagai pengendali perusahaan sehingga muncul konflik kepentingan antar pemilik dan agen yang disebut dengan konflik keagenan (Jensen dan Meckling dalam Rachmawati dan Triatmoko, 2006). Kepemilikan manaje-men adalah proporsi pemegang saham dari pihak manajemen yang secara aktif ikut dalam pengambilan keputusan perusahaan (Diyah dan Erman, 2009).

Manajer yang memiliki kepemilikan saham di perusahaan berbeda dengan manajer yang murni sebagai manajer. Manajer yang sekaligus pemegang saham akan berusaha meningkatkan nilai perusahaan, karena dengan meningkatnya nilai perusahaan maka kesejahteraan sebagai pemegang saham akan meningkat pula. Selain itu manajemen sebagai agen berusaha mengelola perusahan agar terhindar dari kebangkrutan usaha yang akan 
merugikan pemegang saham karena kehilangan return bahkan dana yang diinvestasikan

Kepemilikan institusional memiliki arti penting dalam memonitor manajemen serta mendorong peningkatan pengawasan yang lebih optimal. Semakin tinggi kepemilikan institusional maka akan mengurangi perilaku opportunistic manajer yang dapat mengurangi agency cost yang diharapkan akan meningkatkan nilai perusahaan (Wahyudi dan Pawestri, 2006). Perusahaan dengan kepemilikan institusional yang besar mengindikasikan kemampuannya untuk memonitor manajemen. Semakin besar kepemilikan institusional maka semakin efisien pemanfaatan aktiva perusahaan dan diharapkan juga dapat bertindak sebagai pencegahan terhadap pemborosan yang dilakukan oleh manajemen. Kepemilikan institusional memiliki kemampuan untuk mengurangi insentif para manajer yang mementingkan dirinya sendiri melalui pengawasan yang intensif daripada investor perseorangan (Bushe, 1998 dalam Suranta dan Midiastuty, 2005).

Para pemegang saham institusional akan dapat memonitor tim manajemen secara lebih efektif dan nantinya dapat meningkatkan nilai perusahaan. Tingginya kepemilikan oleh institusi akan meningkatkan pengawasan terhadap perusahaan. Pengawasan yang tinggi ini akan membatasi perilaku opportunistic yang dilakukan pihak manajemen sehingga akan menurunkan nilai perusahaan. Selain itu, pemilik institusional akan berusaha melakukan usaha-usaha positif guna meningkatkan nilai perusahaan miliknya.

Mekanisme Corporate Governance yang digunakan yaitu kepemi- likan manajemen dan kepemilikan institusional karena pemegang saham baik mayoritas maupun minoritas berpengaruh terhadap nilai perusahaan dengan cara menekan manajemen untuk menjaga reputasi perusahaan yang berdampak terhadap naiknya biaya yang dikeluarkan oleh perusahaan untuk menyediakan informasi bagi publik.

\section{TELAAH LITERATUR}

\section{Corporate Governance}

Sebelum membahas lebih jauh mengenai good corporate governance, perlu kiranya memahami terlebih dahulu definisi corporate governance. Corporate Governance merupakan suatu cara untuk menjamin bahwa manajemen bertindak sesuai dengan kepentingan stakeholders (Khomsiyah, 2003). Corporate governance dikenal sebagai mekanisme yang digunakan untuk memastikan bahwa manajemen bertindak yang terbaik untuk kepentingan stakeholders. Pelaksanaan good corporate governance menuntut adanya perlindungan yang kuat terhadap hak-hak pemegang saham, terutama hak pemegang saham minoritas. Prinsip-prinsip atau pedoman pelaksanaan corporate governance menunjukkan adanya perlindungan tersebut, tidak hanya kepada pemegang saham, tetapi meliputi seluruh pihak-pihak yang terlibat dalam perusahaan. Selain itu, corporate governance dikatakan sebagai suatu sistem bagaimana organisasi dikelola dan dikendalikan, antara lain mengatur mekanisme pengambilan keputusan pada tingkat atas organisasi.

Corporate governance pada dasarnya menyangkut masalah siapa (who) yang seharusnya mengendalikan 
jalannya kegiatan korporasi dan mengapa (why) harus dilakukan pengendalian terhadap jalannya korporasi. Yang dimaksud dengan siapa adalah para pemegang saham, sedangkan mengapa adalah karena adanya hubungan antara pemegang saham dengan berbagai pihak yang berkepentingan terhadap perusahaan (Kaen, 2003 dalam Siallagan dan Machfoedz, 2006). Corporate Governance mengatur pola hubungan antara dewan komisaris, direksi, pemegang saham, dan para stakeholders lainnya agar terjadi keseimbangan atas pengambilan keputusan sehingga dapat membatasi pola pengelolaan perusahaan yang salah. Dengan adanya corporate governance yang baik, maka keputusan-keputusan perusahaan yang penting tidak lagi dikendalikan oleh pihak yang dominan, misalkan dewan direksi, tetapi ditetapkan setelah mendapatkan masukan dan pertimbangan dari para stakeholders lainnya.

Kartana (2001) dalam Wignjohartojo (2001) menyatakan corporate governance mengandung dua aspek keseimbangan, yaitu: (i) keseimbangan internal menekankan pada keseimbangan antara organ-organ perusahaan, yaitu Rapat Umum Pemegang Saham (RUPS), Komisaris dan Direksi, yang mencakup hal-hal yang berkaitan dengan struktur kelembagaan dan operasional ketiga organ perusahaan tersebut; (ii) keseimbangan eksternal menekankan pada pemenuhan tanggung jawab perusahaan sebagai entitas bisnis dalam masyarakat kepada seluruh stakeholders, yang mencakup hal-hal yang terkait dengan pengaturan hubungan antara perusahaan dengan seluruh stakeholders.

Selain itu, Ujiyantho dan Pramuka (2007) juga menyatakan bahwa terdapat empat mekanisme corporate governance yaitu memperbesar kepemilikan saham perusahaan oleh manajemen, kepemilikan saham oleh investor institusional, proporsi dewan komisaris independen, dan ukuran dewan komisaris. Mekanisme corporate governance yang digunakan dalam penelitian ini adalah:

(1) Kepemilikan Manajemen.

Kepemilikan manajemen adalah proporsi saham yang dimiliki oleh para manajemen dalam suatu perusahaan (Mehran, 1997 dalam Mardiyah, 2005). Manajemen yang mempunyai saham dalam perusahaan dipandang sebagai penyelaras perbedaan kepentingan antara pemegang saham luar dengan manajemen karena manajemen termotivasi meningkatkan kinerja dan mempunyai tanggung jawab untuk meningkatkan kemakmuran pemegang saham. Dengan demikian kepemilikan saham oleh manajemen merupakan insentif bagi para manajer untuk meningkatkan kinerja perusahaan sehingga akan meminimumkan biaya keagenan (Wahidahwati, 2002).

(2) Kepemilikan Institusional Institusi merupakan sebuah lembaga yang memiliki kepentingan dengan proporsi besar terhadap investasi yang dilakukan termasuk investasi saham, sehingga biasanya investor menyerahkan tanggung jawab pada divisi tertentu untuk mengelola investasi perusahaan tersebut. Dalam hubungannya dengan manajemen laba, ada dua pendapat yang bertentangan menyangkut peran insvestor institusional. Pertama, yang didasarkan pada pandangan bahwa investor institusional adalah pemilik semen- 
tara (transient owners) yang biasanya terfokus pada current earnings (Porter, 1992 dalam Midiastuty dan Machoedz, 2003). Akibatnya manajer terpaksa untuk melakukan tindakan yang dapat meningkatkan laba jangka pendek, misalnya dengan melakukan manajemen laba. Pendapat kedua, memandang investor institusional sebagai investor yang sophisticated sehingga dapat melakukan fungsi monitoring secara lebih efektif dan tidak akan mudah diperdaya dengan tindakan manipulasi oleh manajer seperti tindakan manajemen laba (Bushe, 1998 dalam Midiastuty dan Machoedz, 2003). Perusahaan dengan kepemilikan investor institusional yang besar mendorong untuk mengungkapkan secara sukarela informasi privat yang akan bermanfaat sangat besar. Hal ini memungkinkan mereka melakukan aktivitas monitoring dengan lebih efektif, sehingga dapat membatasi fleksibilitas manajer dalam memilih metode akuntansi untuk merekayasa laba perusahaan demi kepentingan pribadi mereka.

Secara umum menurut The Indonesian Institute For Corporate Governance, terdapat lima prinsip utama yang merupakan bagian dari praktek good corporate governance yang selalu menjadi acuan dalam penyelenggaraan korporasi yaitu (Kaihatu, 2006):

(1) Transparency (keterbukaan informasi). Keterbukaan dalam melaksanakan proses pengambilan keputusan dan keterbukan dalam mengemukakan informasi materiil dan relevan mengenai perusahaan. Transparansi berkaitan dengan ba- nyaknya disclosure atau keterbukaan informasi mengenai kinerja, struktur dan operasi perusahaan. Selain itu, transparansi juga menyangkut ketersediaan informasi yang cukup, akurat, dan tepat waktu kepada seluruh stakeholders.

(2) Accountability (akuntabilitas). Akuntabilitas meliputi kejelasan fungsi, struktur, sistem, dan pertanggungjawaban organ perusahaan sehingga pengelolaan perusahaan berjalan dengan efektif. Akuntabilitas mencerminkan aplikasi sistem internal checks dan balances yang mencakup praktikpraktik audit yang sehat. Dengan demikian akuntabilitas akan tercapai dengan terciptanya pengawasan efektif yang berdasarkan pada pembagian wewenang, peranan, hak, dan tanggung jawab antara pemegang saham, komisaris dan direksi.

(3) Responsibility (pertanggungjawaban). Pertanggungjawaban merupakan kesesuaian (kepatuhan) dalam pengelolaan perusahaan terhadap prinsip korporasi yang sehat serta peraturan perundang-undangan yang berlaku. Hal ini juga mencakup pertanggungjawaban perusahaan kepada stakeholders, yang antara lain meliputi aspekaspek manajerial perusahaan, seperti sasaran dalam mencapai cost efficiency, peningkatan daya saing, menggali setiap potensi dalam memperoleh laba..

(4) Independency (kemandirian), menyangkut keadaan perusahaan yang dikelola secara profesional tanpa benturan kepentingan dan pengaruh atau tekanan dari pihak manajemen yang tidak sesuai 
dengan peraturan perundangundangan yang berlaku serta prinsip-prinsip korporasi yang sehat.

(5) Fairness (kewajaran). Prinsip kewajaran mencakup perlakuan yang sama terhadap para pemegang saham, terutama pada pemegang saham minoritas dan pemegang saham asing, dengan keterbukaan informasi yang penting serta melarang pembagian untuk pihak sendiri dan perdagangan saham oleh orang dalam.

Secara keseluruhan, prinsipprinsip corporate governance dapat mencegah dan mengatasi perilaku manajemen yang menyimpang dan merugikan para stakeholders. Dengan beberapa prinsip dasar tersebut diharapkan corporate governance memberikan arti yang sangat penting dalam membentuk korporasi yang responsif dan demokratis terhadap berbagai keadaan, misalnya, tekanan pasar, tantangan investasi baru, dan peluang untuk tumbuh berkembang dalam masyarakat yang dinamis.

\section{Nilai Perusahaan}

Nilai perusahaan sangat penting karena dengan nilai perusahaan yang tinggi akan diikuti oleh tingginya kesejahteraan pemegang saham yang tercermin melalui harga saham. Kesejahteraan pemegang saham dan perusahaan dipresentasikan oleh harga pasar dari saham yang merupakan cerminan dari keputusan investasi, pendanaan (financing), dan manajemen asset. Memaksimalkan nilai perusahaan tidak sama dengan memaksimalkan laba. Memaksimalkan nilai perusahaan meliputi aspek yang lebih luas dari memaksimalkan keuntungan/laba (Susanti dkk, 2010)

Aspek-aspek sebagai pedoman perusahaan untuk memaksimalkan nilai perusahaan adalah sebagai berikut:

(a) Menghindari Risiko yang Tinggi. Bila perusahaan sedang melaksanakan operasi yang berjangka panjang, maka harus dihindari tingkat risiko yang tinggi. Proyekproyek yang memiliki kemungkinan laba yang tinggi tetapi mengandung risiko yang tinggi perlu dihindarkan. Menerima proyek-proyek tersebut dalam jangka panjang berarti suatu kegagalan yang dapat mematahkan kelangsungan hidup perusahaan.

(b) Membayarkan Dividen.

Dividen adalah pembagian laba kepada para pemegang saham oleh perusahaan sesuai dengan jumlah kepemilikan pemegang saham. Pada saat perusahaan sedang mengalami kenaikan dividen tidak terlalu signifikan, perlu adanya kebijakan untuk menahan dividen tersebut sampai periode selanjutnya. Namun, apabila keadaan perusahaan sudah mampu membayar dividen, maka akan dibayarkan ssuai dengan persentase kepemilikan. Dengan membayarkan dividen secara wajar, maka perusahaan dapat membantu menarik para investor untuk mencari dividen dan hal ini dapat membantu memelihara nilai perusahaan.

(c) Mengusahakan Pertumbuhan.

Apabila perusahaan dapat mengembangkan penjualan, hal ini dapat berakibat terjadinya keselamatan usaha di dalam per- 
saingan di pasar. Maka perusahaan yang akan berusaha memaksimalkan nilai perusahaan harus secara terus-menerus mengusahakan pertumbuhan dari penjualan dan penghasilannya.

(a) Mempertahankan Tingginya Harga Pasar Saham.

Harga saham di pasar adalah merupakan perhatian utama dari manajer keuangan untuk memberikan kemakmuran kepada para pemegang saham atau pemilik perusahaan. Manajer harus selalu berusaha ke arah itu untuk mendorong masyarakat agar bersedia menanamkan uangnya ke dalam perusahaan itu. Dengan pemilihan investasi yang tepat maka perusahaan akan mencerminkan petunjuk sebagai tempat penanaman modal yang bijaksana bagi masyarakat. Hal ini akan membantu mempertinggi nilai dari perusahaan. Memaksimalkan keuntungan/laba bertumpu pada pandangan jangka pendek perusahaan.

Jika sekedar ingin meningkatkan keuntungan perusahaan, manajemen perusahaan dapat menerbitkan saham baru untuk memperoleh tambahan dana yang kemudian diinvestasikan untuk mendapatkan tambahan keuntungan. Tapi jika keuntungan tambahan yang diperoleh lebih rendah, penghasilan per lembar saham justru akan menurun. Nilai perusahaan juga dipengaruhi faktor-faktor diantaranya struktur modal dalam perusahaan, hubungan antara principal dengan pihak manajemen dan kemampuan perusahaan dalam menghasilkan profit.

Berbagai macam indikator ekonomi yang digunakan untuk mengukur kinerja dalam bisnis. Tobin's $q$ sebagai salah satu indikator pengukur variabel kinerja perusahaan dari perspektif investasi telah diuji di berbagai situasi manajemen puncak. Nilai Tobin's $q$ menggambarkan suatu kondisi peluang investasi yang dimiliki perusahaan atau potensi pertumbuhan perusahaan. Nilai Tobin' $q$ dihasilkan dari penjumlahan nilai pasar saham (market value of all outstanding stock) dan nilai pasar hutang (market value of all debt) dibandingkan dengan nilai seluruh modal yang ditempatkan dalam aktiva produksi (replacement value of all production capacity), maka Tobin's $q$ dapat digunakan untuk mengukur kinerja perusahaan, yaitu dari sisi potensi nilai pasar suatu perusahaan. pengukur kinerja dengan membandingkan dua penilaian dari asset yang sama. Tobin's $q$ merupakan rasio dari nilai pasar asset perusahaan yang diukur oleh nilai pasar dari jumlah saham yang beredar dan hutang (enterprise value) terhadap replacement cost dari aktiva perusahaan (Fiakas, 2005).

\section{HIPOTESIS}

Sesuai dengan tujuan penelitian yang ingin dicapai dan hasil penelitian terdahulu, maka peneliti mencoba merumuskan beberapa hipotesis, yaitu:

a. Pengaruh Kepemilikan Manajemen terhadap Nilai Perusahaan

Kepemilikan manajemen terhadap saham perusahaan dipandang dapat menyelaraskan potensi perbedaan kepentingan antara pemegang saham luar dengan manajemen. Adanya kepemilikan manajemen diharapkan tidak hanya bekerja untuk kepentingan pemegang saham eksternal namun demi kepentingannya sendiri, karena 
mereka juga merupakan bagian dari pemegang saham. Kinerja manajer akan semakin baik dan semakin meningkatkan nilai perusahaan sehingga keinginan para principal karena manajer akan termotivasi untuk meningkatkan kinerja (Siallagan dan Machfoedz, 2006).

H1 : Kepemilikan manajerial berpengaruh signifikan terhadap nilai perusahaan.

b. Pengaruh Kepemilikan Institusional terhadap Nilai Perusahaan

Kepemilikan institusional merupakan saham perusahaan yang dimiliki oleh institusi atau lembaga seperti perusahaan asuransi, bank, perusahaan investasi, dan kepemilikan institusi lain. Pemegang saham perusahaan tidak terbatas pada individu saja, tetapi juga pihak institusional. Institusional sebagai pihak yang tidak mau dirugikan karena memiliki andil dalam perusahaan berupa kepemilikan saham akan berusaha melakukan pengawasan seoptimal mungkin terhadap kinerja manajerial (Boediono, 2005). Dengan kata lain pihak institusional memiliki kemampuan untuk mengontrol dan memonitor tindakan manajer yang mementingakan dirinya sendiri yang disebabkan oleh asimetri informasi melalui tingkat pengawasan yang intensif. Keberadaan investor institusional dianggap mampu menjadi mekanisme monitoring yang efektif dalam setiap keputusan yang diambil oleh manajer. Hal ini disebabkan investor institusional terlibat dalam pengambilan yang strategis sehingga tidak mudah percaya terhadap tindakan manipulasi laba. Dari penjelasan tersebut, maka dapat dibuat hipotesis sebagai berikut:

H2 : Kepemilikan institusional berpengaruh signifikan terhadap manajemen laba.

\section{METODE PENELITIAN}

Penelitian ini merupakan jenis penelitian dengan hipotesis yang bertujuan untuk menguji pengaruh corporate governance terhadap nilai perusahaan pada seluruh perusahaan manufaktur yang terdaftar di Bursa Efek Indonesia mulai tahun 2012 sampai 2013.

\section{Identifikasi Variabel}

Dalam penelitian ini variabelvariabel yang digunakan:

a. Variabel independen yaitu kepemilikan manajemen (MGR), kepemilikan institusional (INST).

b. Variabel dependen yaitu nilai perusahaan (Q).

\section{Definisi Operasional Variabel}

Definisi operasional masingmasing variabel penelitian adalah sebagai berikut:

a. Kepemilikan Manajemen (MGR), yaitu kepemilikan saham oleh pihak manajemen perusahaan dalam suatu perusahaan yang diukur dari persentase jumlah saham yang dimiliki pihak manajemen perusahaan terhadap total jumlah saham yang beredar tiap tahun (Boediono, 2005).

b. Kepemilikan Institusional (INST), yaitu kepemilikan saham oleh pihak institusional dalam suatu perusahaan yang diukur dari persentase jumlah saham yang dimiliki oleh investor institusional terhadap total jumlah saham yang 
beredar tiap tahun (Midiastuty dan Machfoedz, 2003).

c. Nilai Perusahaan (Q), nilai perusahaan diukur dengan menggunakan Tobin's Q. Tobin's $\mathrm{Q}$ dibawah 1 menggambarkan saham dalam kondisi undervalued. Manajemen telah gagal dalam mengelola aktiva perusahaan. Potensi pertumbuhan investasi rendah. Tobin's $\mathrm{Q}=1$ menggambarkan saham dalam kondisi average. Manajemen stagnan dalam mengelola aktiva. Potensi pertumbuhan investasi tidak berkembang. Tobin's Q diatas 1 menggambarkan bahwa saham dalam kondisi overvalued. Manajemen berhasil dalam mengelola aktiva perusahaan. Potensi pertumbuhan investasi tinggi.

Sudiyanto dan Puspitasari (2010) menggunakan rumus yang digunakan dalam penelitian ini merupakan modifikasi Tobin's $q$ versi Chung dan Pruitt (1994) yang telah digunakan secara konsisten karena disederhanakan diberbagai simulasi permainan. Formulasi rumusnya sebagai berikut:

$$
\begin{aligned}
\mathrm{Q} & =\frac{(\mathrm{MVS}+\mathrm{D})}{\mathrm{TA}} \\
& =\frac{(\mathrm{MVS}+((\mathrm{AVCL}-\mathrm{AVCA})+\mathrm{AVLTD}))}{\mathrm{TA}}
\end{aligned}
$$

di mana:

MVS = Market value of all outstanding shares. Market value of all outstanding shares (MVS) merupakan nilai pasar saham yang diperoleh dari perkalian jumlah saham yang beredar dengan harga saham (Outstanding Shares $x$ Stock Price).

D $\quad=$ Debt merupakan besarnya nilai pasar hutang.

AVCL = Accounting value of the firm's Current Liabilities. Merupakan penjumlahan antara Short Term Debt dan Taxes Payable.

AVLTD = Accounting value of the firm's Long Term Debt.

AVCA = Accounting value of the firm's Current Assets. Merupakan penjumlahan antar Cash, Account Receivable dan Inventories.

TA = Firm's asset's, merupakan total seluruh perusahaan.

\section{Jenis dan Sumber Data}

Jenis data yang digunakan dalam penelitian adalah data kuantitatif laporan keuangan perusahaan manufaktur yang terdaftar di Bursa Efek Indonesia mulai tahun 2012 sampai tahun 2013. Sumber data dalam penelitian ini adalah Indonesian Capital Market Directory (ICMD), serta website BEI (www.idx.co.id) berupa data sekunder.

\section{Populasi, Sampel dan Teknik Pengambilan Sampel}

Populasi dalam penelitian ini adalah semua perusahaan manufaktur yang terdaftar di Bursa Efek Indonesia tahun 2012-2013. Teknik pengambilan sampel dilakukan dengan menggunakan metode purposive sampling dengan kriteria perusahaan manufaktur yang terdaftar di Bursa Efek Indonesia secara berturut-turut selama periode 
penelitian tahun 2012-2013 serta mempunyai data mengenai kepemilikan manajerial, kepemilikan institusional secara berturut-turut mulai dari tahun 2012 sampai dengan 2013. Sehingga didapat sampel berjumlah 32 perusahaan per tahun.

\section{Teknik Analisis Data}

Teknik analisis data yang digunakan dalam penelitian ini antara lain:

a. Menghitung Tobin Q dengan mencari nilai MVS dan DEBT.

b. Menghitung persentase kepemilikan manajerial dan persentase kepemilikan institusional.

c. Seluruh variabel independen dan dependen dimasukkan ke dalam model analisis untuk diregresikan dengan bantuan program SPSS 15 menggunakan persamaan: $\mathrm{Q}=\beta_{0}+\beta_{1} \mathrm{MGR}+\beta_{2} \mathrm{INST}+\mathrm{e}$

a. Melakukan uji asumsi klasik. Menurut Ghozali (2006), agar model regresi menghasilkan estimasi yang tidak bias maka harus memenuhi empat asumsi klasik.

b. Pengujian hipotesis dalam penelitian menggunakan regresi linier berganda (Uji-F dan Uji-t).

\section{ANALISIS DAN PEMBAHASAN}

\section{Gambaran Umum Obyek Penelitian}

Populasi yang digunakan dalam penelitian ini adalah semua perusahaan manufaktur yang terdaftar di Bursa Efek Indonesia periode 2012-2013. Pemanufakturan berarti pengelolaan dengan tangan atau mesin. Perusahaan manufaktur mengolah bahan baku atau bahan mentah menjadi bahan setengah jadi, kemudian mengolahnya kembali menjadi bahan jadi. Perusahaan manufaktur memiliki tiga fungsi utama, yaitu kegiatan produksi, penjualan, dan administratif/umum. Secara fisik ketiga kegiatan tersebut sering dipisahkan, sehingga dalam suatu perusahaan terdapat tiga kegiatan tersebut (Suwardjono, 2003).

\section{Deskripsi Data}

Statistik deskriptif pada Tabel 1 menunjukkan nilai perusahaan (Q) memiliki nilai minimum -0,1692 dan nilai maksimum 1,20087. Nilai ratarata $Q$ adalah 1,41839688 dan bertanda positif yang artinya perusahaan yang menjadi sampel ratarata memiliki nilai perusahaan yang positif. Tobin's $\mathrm{Q}$ diatas 1 menggambarkan bahwa saham dalam kondisi overvalued. Manajemen berhasil dalam mengelola aktiva perusahaan. Potensi pertumbuhan investasi tinggi MGR memiliki nilai minimum 0,000010 dan nilai maksimum 0,728200 dengan standar deviasi sebesar 0,108415938. Nilai rata-rata MGR adalah 0,063841406 menunjukkan bahwa pihak manajemen perusahaan (komisaris dan direksi) yang menjadi sampel memiliki sebagian kecil saham perusahaan. INST memiliki nilai minimum 0,05490 dan nilai maksimum 0,9522 serta standar deviasi sebesar 0,174748949 . Nilai rata-rata INST adalah 0,6356225 yang menunjukkan bahwa saham perusahaan yang menjadi sampel sebagian besar dimiliki oleh pihak institusional. 
Tabel 1

Tabel Statistik Deskriptif

\begin{tabular}{|l|l|r|r|l|c|}
\hline \multicolumn{6}{|l|}{$\begin{array}{l}\text { Descriptive } \\
\text { Statistics }\end{array}$} \\
\hline
\end{tabular}

\section{Analisis Data}

Tabel 2 menunjukkan nilai $\mathrm{R}^{2}$ adalah 0,257 yang menunjukkan sebesar 25,7\% variabel independen yaitu kepemilikan manajemen dan kepemilikan institusional mempu menjelaskan variabel dependen yaitu nilai perusahaan yang diproksikan dengan Q. Sedangkan sisanya 74,3\% dijelaskan oleh variabel lain selain variabel yang digunakan. Hal ini mengindikasikan masih banyak faktor yang mempengaruhi nilai perusahaan. Berdasarkan hasil signifikansi uji-F pada Tabel 2 yang menunjukkan angka probabilitas < 0,05 yaitu sebesar 0,014, maka disimpulkan variabel independen (kepemilikan manajemen dan kepemilikan institusional) secara simultan berpengaruh terhadap variabel dependen yaitu nilai perusahaan. Hasil signifikansi uji-t pada Tabel 2 menunjukkan bahwa kepemilikan manajemen (MGR) berpengaruh secara signifikan terhadap nilai perusahaan $(\alpha=0,004)$ dan kepemilikan institusional (INST) tidak berpengaruh terhadap nilai perusahaan $(\alpha=0,055)$.

Tabel 2

Tabel Uji-F dan Uji -t

Variables Entered/Removed(b)

\begin{tabular}{|l|l|l|l|}
\hline Model & $\begin{array}{c}\text { Variables } \\
\text { Entered }\end{array}$ & $\begin{array}{l}\text { Variables } \\
\text { Removed }\end{array}$ & Method \\
\hline 1 & INST, MGR(a) &. & Enter \\
\hline
\end{tabular}

a. All requested variables entered.

b. Dependent Variable: Q

\begin{tabular}{|c|c|c|c|c|}
\hline \multicolumn{5}{|c|}{ Model Summary } \\
\hline Model & $\mathrm{R}$ & R Square & $\begin{array}{l}\text { Adjusted R } \\
\text { Square }\end{array}$ & $\begin{array}{l}\text { Std. Error } \\
\text { of the } \\
\text { Estimate }\end{array}$ \\
\hline 1 & ,507(a) & 0,257 & 0,232 & 0,17163 \\
\hline
\end{tabular}

a. Predictors: (Constant), INST, MGR 
ANOVA(b)

\begin{tabular}{|ll|r|r|r|r|l|}
\hline Model & & $\begin{array}{c}\text { Sum of } \\
\text { Squares }\end{array}$ & Df & $\begin{array}{c}\text { Mean } \\
\text { Square }\end{array}$ & F & Sig. \\
\hline 1 & Regression & 0,621 & 2 & 0,310 & 10,535 &, $014(\mathrm{a})$ \\
& Residual & 1,797 & 61 & 0,029 & & \\
& Total & 2,417 & 63 & & & \\
\hline
\end{tabular}

a. Predictors: (Constant), INST, MGR

b. Dependent Variable: Q

Coefficients(a)

\begin{tabular}{|ll|r|r|r|r|r|}
\hline \multirow{2}{*}{ Model } & \multicolumn{2}{|c|}{$\begin{array}{c}\text { Unstandardized } \\
\text { Coefficients }\end{array}$} & \multicolumn{1}{c|}{$\begin{array}{c}\text { Standardized } \\
\text { Coefficients }\end{array}$} & & \\
\cline { 3 - 5 } & & \multicolumn{1}{c|}{$\mathrm{B}$} & Std. Error & Beta & \multicolumn{1}{c|}{$\mathrm{t}$} & \multicolumn{1}{c|}{ Sig. } \\
\hline 1 & (Constant) & 0,244 & 0,095 & & 2,561 & 0,013 \\
& MGR & 0,653 & 0,219 & 0,361 & 2,987 & 0,004 \\
& INST & $-0,265$ & 0,136 & $-0,237$ & $-1,955$ & 0,055 \\
\hline
\end{tabular}

a. Dependent Variable: $\mathrm{Q}$

\section{Pembahasan}

Berdasarkan Tabel 2 diperoleh persamaan regresi berganda sebagai berikut:

$\mathrm{Q}=0,244+0,653 \mathrm{MGR}$ - 0,265 INST

Kepemilikan manajemen (MGR) memiliki nilai signifikansi sebesar 0,004 sehingga dapat disimpulkan bahwa kepemilikan manajemen berpengaruh secara parsial terhadap nilai perusahaan. Hubungan kepemilikan manajemen terhadap nilai perusahaan adalah positif dengan nilai koefisien sebesar 0,653. Jika dilihat dari pola hubungan kepemilikan manajemen dengan nilai perusahaan yang positif, maka dapat diartikan bahwa semakin tinggi kepemilikan manajemen dalam suatu perusahaan semakin tinggi nilai perusahaan. Hal ini menunjukkan bahwa kepemilikan manajemen mampu menjadi mekanisme corporate governance yang dapat mengurangi ketidakselarasan kepentingan antara manajemen sebagai agen dengan pemilik. Hasil penelitian ini sesuai dengan yang dilakukan oleh Wahyudi dan Pawestri (2006) yang menyatakan bahwa kepemilikan manajerial berpengaruh terhadap nilai perusahaan

Manajer yang memiliki kepemilikan saham di perusahaan berbeda dengan manajer yang murni sebagai manajer. Manajemen sebagai agen dan pemilik perusahaan akan berusaha untuk memaksimalkan kesejahteraannya seiring dengan meningkatnya nilai perusahaan. Manajemen menyelaraskan kepentingan antara pihak internal dan eksternal sehingga perusahaan akan terhindar dari kebangkrutan yang mengakibatkan pemegang saham kehilangan return bahkan dana yang diinvestasikan.

Selanjutnya, kepemilikan institusional (INST) memiliki nilai signifikansi sebesar 0,055 sehingga dapat disimpulkan bahwa kepemilikan institusional tidak berpengaruh secara parsial terhadap nilai perusahaan. Besarnya persentase kepemilikan institusional tidak berdampak pada nilai perusahaan. Jumlah pemegang saham yang besar tidak efektif dalam memonitor perilaku manajemen dalam perusahaan. Manajemen terkadang 
melakukan tindakan opportunistic yang tidak dapat dideteksi dengan adanya pengawasan oleh pihak institusional. Hal ini terjadi karena adanya asimetri informasi antara pihak manajemen dengan pihak institusional. Manajemen memiliki lebih banyak informasi tentang perusahaan daripada pihak institusional, sehingga pengawasan yang dilakukan tidak berpengaruh terhadap harga saham. Hasil penelitian ini sesuai dengan Sofyaningsih dan Hardiningsih (2011) dan Haruman (2007) yang membuktikan bahwa kepemilikan institusional tidak berpengaruh terhadap nilai perusahaan.

Kepemilikan Manajemen (MGR) dan kepemilikan institusional (INST) secara bersama sama berpengaruh terhadap nilai perusahaan (Q) yang memiliki nilai signifikansi sebesar 0,014. Hasil ini menunjukkan bahwa kepemilikan manajemen dan kepemilikan institusional mampu menjadi mekanisme corporate governance dalam meningkatkan nilai perusahaan. Manajemen sebagai agen sekaligus pemilik telah melakukan tugasnya dengan baik demi peningkatan kesejahteraan dirinya sendri. Selain itu, fungsi pengawasan yang dilakukan oleh pemegang saham institusional telah berjalan efektif, sehingga terjadi keselarasan kepentingan antara pihak insider ataupun outsider perusahaan.

\section{KESIMPULAN}

Dari hasil analisis dan pembahasan, maka dapat ditarik kesimpulan bahwa:

1. Kepemilikan manajerial dan kepemilikan institusional berpengaruh secara simultan (bersama-sama) terhadap nilai perusahaan.
2. Secara parsial kepemilikan manajerial berpengaruh terhadap nilai perusahaan, hal ini menunjukkan bahwa kepemilikan manajerial mampu menjadi mekanisme corporate governance yang dapat mengurangi ketidakselarasan kepentingan antara manajemen dengan pemilik atau pemegang saham. Kepemilikan institusional tidak berpengaruh terhadap nilai perusahaan. Besarnya persentase kepemilikan institusional tidak berdampak pada nilai perusahaan. Jumlah pemegang saham yang besar tidak efektif dalam memonitor perilaku manajemen dalam perusahaan. Manajemen terkadang melakukan tindakan opportunistic yang tidak dapat dideteksi dengan adanya pengawasan oleh pihak institusional. Hal ini terjadi karena adanya asimetri informasi antara pihak manajemen dengan pihak institusional. Manajemen memiliki lebih banyak informasi tentang perusahaan daripada pihak institusional, sehingga pengawasan yang dilakukan tidak berpengaruh terhadap harga saham.

\section{SARAN}

Berdasarkan hasil penelitian dan simpulan, maka diberikan beberapa saran bagi penelitian selanjutnya sebagai berikut:

1. Penelitan ini menggunakan variabel independen mekanisme corporate governance yaitu kepemilikan manajemen dan kepemilikan institusional diharapkan bagi penelitian selanjutnya menambahkan variabel yang lain, misalkan komisaris independen, komite audit, deviden, dan lain sebagainya. 
2. Penelitian ini memfokuskan pada industri manufaktur diharapkan bagi penelitian selanjutnya yaitu mengembangkan fokus perhatiannya pada indsutri selain manufaktur misalkan, industri keuangan, industri jasa, dan industri telekomunikasi sehingga diketahui pengaruh mekanisme corporate governance terhadap manajemen laba pada industri lain.

3. Penelitian ini menggunakan periode 2012-2013, diharapkan bagi penelitian selanjutnya menggunakan periode yang berbeda sehingga dapat digunakan sebagai sebagai bahan pembanding.

\section{DAFTAR KEPUSTAKAAN}

Boediono, Gideon SB, 2005, Kualitas Laba: Studi Pengaruh Mekanisme Corporate Governance dan Dampak Manajemen Laba Dengan Menggunakan Analisis Jalur, Simposium Nasional Akuntansi VIII, Solo, hal. 172193.

Diyah, Pujiati dan ErmanWidanar, 2009, Pengaruh Struktur Kepemilikan terhadap Nilai Perusahaan, Keputusan Keuangan sebagai Variabel Intervening, Jurnal Ekonomi Bisnis dan Akuntansi Ventura, Vol. 12, No. 1, hal. 71-86.

Fiakas. D, 2005, Tobin's Q : Valuing Small Capotalization Companies, Crystal Equity Reserach, April.

Ghozali, Imam, 2006, Aplikasi Analisis Multivariate dengan Program SPSS, Badan penerbit Universitas Diponegoro, Yogyakarta.
Haruman, Tendi, 2007, Pengaruh Keputusan Keuangan dan Kepemilikan Institusional terhadap Nilai Perusahaan, The First National PPM Management Research "Manajemen di Era Globalisasi”, Bandung.

Kaihatu, Thomas. S., 2006, Good Corporate Governance dan Penerapannya di Indonesia, Jurnal Manajemen dan Kewirausahaan, Vol. 8, No. 1, hal. 1-9.

Khomsiyah, 2003, Hubungan Corporate Governance dan Pengungkapan Informasi: Pengujian Secara Simultan, Simposium Nasional Akuntansi VI, Surabaya, Oktober, hal. 200-213.

Mardiyah, Aida Ainul, 2005, Pengaruh Struktur Kepemilikan Managerial, Earnings Management, dan Free Cash Flow Terhadap Utang dan Kinerja, Konferensi Nasional Akuntansi, Jakarta, September, hal. 1-27.

Midiastuty, Pranata Puspa, dan Mas'ud Machfoedz, 2003, Analisis Hubungan Mekanisme Corporate Governance dan Indikasi Manajemen Laba, Simposium Nasional Akuntansi VI, Surabaya, Oktober, hal. 176198.

Rachmawati, Andri dan Hanung Triatmoko, 2007, Analisis Faktor Faktor yang Mempengaruhi Kualitas Laba dan Nilai Perusahaan, Simposium Nasional Akuntansi X, Makasar, Juli, hal. 1-26. 
Siallagan, Homonangan, dan Mas'ud Machfoedz, 2006, Mekanisme Corporate Governance, Kualitas laba dan Nilai Perusahaan, Simposium Nasional Akuntansi IX, Padang, Agustus, hal. 1-23.

Sofyaningsih Sri, dan Hardiningsih Pancawati, 2011, Struktur Kepemilikan, Kebijakan Deviden, Kebijakan Hutang dan Nilai Perusahaan, Dinamika Keuangan dan Perbankan, Vol. 3, No. 1, hal. 68-87.

Sudiyanto, Bambang, dan Elen Puspitasari, 2010, Tobin's Q dan Almtan $Z$ Score sebagai Pengukuran Kinerja Perusahaan, Kajian Akuntansi, Vol. 2, No. 1, hal. 9-21.

Suranta, Eddy, dan Pranata Puspa Midiastuty, 2005, Pengaruh Good Corporate Governance terhadap Praktek Manajemen Laba, Konferensi Nasional Akuntansi, Jakarta, September, hal. 1-18.

Susanti, Agraheni Niken, Rahmawati, Y. Anni Aryani, 2010, Analisis Pengaruh Corporate Governance dengan Kualitas Laba sebagai Variabel Intervening pada Perusahaan Manufaktur yang Terdaftar di Bursa Efek Indonesia periode 2004-2007, Simposium Nasional Keuangan I, Surabaya, hal. 1-26.
Suwardjono, 2003, Akuntansi Pengantar Bagian 1, BPFE, Yogyakarta.

Ujiyantho, Muh. Arief, dan Bambang Agus Pramuka, 2007, Mekanisme Corporate Governance, Manajemen Laba dan Kinerja Keuangan, Simposium Nasional Akuntansi X, Makasar, Juli, hal. 1-26.

Wahidahwati, 2002, Pengaruh Kepemilikan Managerial dan Kepemilikan Institusional pada Kebijakan Hutang Perusahaan: Sebuah Perspektif Theory Agency, Jurnal Riset Akuntansi Indonesia, Vol. 5, No. 1, hal. 1-16.

Wahyudi dan Pawestri, 2006, Implikasi Struktur Kepemilikan terhadap Nilai Perusahaan : Dengan Keputusan Keuangan sebagai Variabel Intervening, Simposium Nasional Akuntansi IX, hal. 1-25.

Wignjohartojo, Prawoto, 2001, Good Corporate Governance Implementasi Beserta Implikasi dan Masa Depannya, Majalah Ekonomi, Tahun XI, No. 1, hal. 64-77.

www.idx.co.id/id.id/beranda/perusahaantercatat/laporankeuangandan tahunan.aspx, diakses tanggal 22 Mei 2014 pukul 18.45 WIB. 